\title{
Moving Forward: from the Past to the Future
}

\section{Claire Major $^{1}$}

Published online: 28 January 2020

(C) Springer Nature B.V. 2020

Dear Readers,

Welcome to Volume 45, Issue 2, of Innovative Higher Education! I am thrilled to have the honor of becoming the next editor of this important publication, and I look forward to years of Innovation to come!

To begin my work, I want to thank those who have come before me and have moved this journal forward. Dr. Ronald Simpson, former director of the Office of Instructional Development at the University of Georgia and Professor in the Institute of Higher Education, was editor from 1989 to 2002; Ron did a wonderful job of advancing scholarship on teaching and learning during his tenure. Dr. Libby Morris, Zell B. Miller Distinguished Professor of Higher Education and Director of the Institute of Higher Education at The University of Georgia, served as editor from 2003 to 2019; Libby also did a wonderful job of advancing scholarship, with her keen insights into the field of higher education and deep scholarly knowledge. I received my doctoral degree from the Institute of Higher Education and so had the opportunity to study with both Ron and Libby prior to becoming a professor of higher education myself. They are wonderful teachers and mentors who are now wonderful colleagues, and I am grateful to them personally and professionally.

My thanks also goes to Dr. Kay Herr Gillespie, Professor Emerita of Colorado State University, former President and long-time Director of the Professional and Organizational Development Network, and Associate Editor of this journal for the past 25 years. In the editor's notes of 42(1), Libby described Kay as "the lodestar for the journal overall." I heartily concur and can confirm how central and important Kay has been not only to this journal but also to me personally over time. Kay edited the first scholarly article that I published more than 20 years ago (in Innovative!). She has been an advisor and confidant as I have served on the Editorial Board for the journal, and she has provided me with invaluable training and support as I have learned the inner workings of publishing this particular journal. She has my gratitude for all of the support.

Innovative Higher Education clearly has a distinguished 45-year history, and it remains a journal that is well worth the time and effort to read. It is chock-full of descriptions and

Claire Major

cmajor@ua.edu

1 Higher Education Administration, The University of Alabama, 328C Graves Hall, Box 870302,

Tuscaloosa, AL 35487, USA 
evaluations of teaching methods and programs. It focuses on the effect of innovations on teaching and learning, faculty members, and students; and it provides a nice balance between theory and practice. In addition, the journal publishes amazing authors, both new and established, who are a credit to higher education research. Moreover, the journal has an outstanding Editorial Board with members who are experts on a variety of issues and research methods.

The question now is what is next for Innovative Higher Education. How do we remain truly innovative after 45 years? How can we continue to capture the best thinking, the most innovative practices, and the most outstanding research methods across higher education? How can we move the journal's outstanding reputation to even higher levels in the world of academic publishing?

Only time will tell, but here are a few "innovative" things that I hope to see in future volumes and issues of Innovative Higher Education.

Innovative Topics and Ideas When I think of an innovative topic or idea, I think of something that's truly creative, fresh, and new. This idea may be divergent, in that it is flexible and original and takes us in a new direction. It may involve new ways of thinking about systems or the synthesis of a whole. Or it may be inspirational, providing emergent or radical insight.

Innovative Applications An innovative application means a new approach to translating fundamental knowledge to practical applications in a way that solves problems of individuals and institutions. This category can also mean applying knowledge to existing problems but in new contexts or with new populations.

Innovative Research Methods Our knowledge of the best ways to discover new knowledge is continually evolving. Innovative research methods mean capitalizing on these new approaches when discovering new knowledge. To be an innovative research method could also mean drawing on a new theory, using a new research design, using new forms of data collection, or adopting fresh approaches to data analysis and interpretation.

Innovative Findings To be truly innovative, findings must contribute something new to the field. They may extend an existing line of research. They may refute previous findings. Or they may involve discovering something that is entirely different from what we have previously known. Moreover, innovative findings may mean presenting findings through new forms of representation.

Innovation is a constant in higher education. In this journal we will continue to seek out innovations and share that information with our readers. I look forward to the years to come and seeing the direction in which we next take this journal.

Publisher's Note Springer Nature remains neutral with regard to jurisdictional claims in published maps and institutional affiliations. 